\title{
The importance of narrative medicine in palliative care
}

\section{Abstract}

This article discusses narrative medicine, i.e. drawing knowledge from the narratives of both patients and medical staff. Information obtained in this way can be used in the diagnosis and treatment process and it also has an educational value. This article aims to present the importance of using narrative medicine for palliative care, as well as building relations between doctors and patients. Challenges related to narratives were identified, with their particular significance during the current COVID-19 pandemic taken into account as well.

Palliat Med Pract 2021; 15, 1: 64-69

Key words: communication, cultural context, narrative medicine, narrative, story telling

For humans, life is meaningful because it is a story

(Franke, 2016)

\section{Introduction}

Narrative medicine emphasizes how stories told by both patients and medical staff can increase empathy and provide vital information on the interpretation and significance of illnesses and treatments [1, 2]. It has gained importance and popularity in recent years, especially in palliative care $[3,4]$. In this context, the main aim of narrative medicine is to provide comprehensive care for patients, as well as recognise and interpret illness-related narratives through the integration of medicine and social sciences. Strengthening the doctor-patient relationships and providing more humane, ethical and effective patient-centred care is particularly vital. Not only does increasing the competencies in this field improve the communication process, but it also positively affects teamwork, e.g. it increases the level of professionalism by stimulating people's ability to reflect $[3,5]$.

The popularity of qualitative methods in scientific research, including narrative analysis of the subjects [6], is increasing and this also applies to palliative care [7]. At the same time, the narratives of patients suffering from chronic illnesses are not only an interesting material for scientific analysis but also a basis for supporting the diagnosis and treatment process. By actively participating in their medical history sharing process, it is possible to significantly improve the patients' communication with the medical staff, as well as raise the quality of life of both patients and their caretakers, including healthcare professionals. Listening to a patient's story about their illness makes it possible to increase their confidence in the staff and medicine as a science, as well as to increase their sense of dignity; furthermore, narrative medicine

\footnotetext{
Address for correspondence:

Agata Rudnik

Institute of Psychology, University of Gdansk, Poland

e-mail: agata.rudnik@ug.edu.pl

DOI: 10.5603/PMPI.2021.0002
}

This article is available in open access under Creative Common Attribution-Non-Commercial-No Derivatives 4.0 International (CC BY-NC-ND 4.0) license, allowing to download articles and share them with others as long as they credit the authors and the publisher, but without permission to change them in any way or use them commercially. 
encourages reflection on both the here and now and the meaning of life in general [3].

Rita Charon of Columbia University, who first used the term in 2000 when referring to a clinical practice enhanced by narrative competence - the ability to interpret and immerse oneself in illness-related storytelling - is considered the founder of narrative medicine $[1,8]$. The author's research concerns primarily the communication between doctors and patients and the use of narrative competence to improve the quality of medical care $[8,9]$. According to Rita Charon, both the illness and the recovery process are the so-called narrative acts, whereas writing about one's experiences allows doctors and patients alike to verbalise and systematise the chaos related to the illness situation [9]. Beck agrees with Charon's opinion and states that "by taking the time to talk with my patients about their lives, I find that we establish a rapport over time that is personally rewarding for both of us" [10]. Beck also emphasizes that writing narratives enables doctors to expand medical practice with a unique kind of understanding.

Rita Charon also referred to narrative evidence-based medicine (NEBM), which gathers data from all sources available - including patient-written illness narratives, aesthetic theories of illness, as well as phenomenological theories of embodiment [11]. Under NEBM, the diagnosis and treatment process is based on a well-established, rigorous, personal and concrete interpretation of the information and hypotheses obtained [11].

\section{Narrative medicine in palliative care}

It has been indicated that narrative medicine promotes the diverse competencies of health professionals $[3,8]$, with the goal being to strengthen the doctor-patient relationship through ethical, effective and appropriate patient-centred care [3]. The integration of narrative medicine and palliative care appears to be an effective way of dealing with the hardship of illness and death [12]. According to DeBenedetto et al., "when there is apparently nothing to do, one can still listen" and "if a story's only possible ending is death, it can be written in many ways" [13].

The patient-doctor relationship plays a vital role in the treatment process, influencing the patient's decisions on undertaking and continuing therapy, as well as other factors. This is an important factor in oncology and palliative care, as medical staff often balance between honesty and hope. Although important in the treatment of many illnesses, open communication that preserves patient dignity and autonomy is of exceptional significance in this case [14]. Patients with incurable illnesses often feel isolated from the life around them and believe they are a burden to their loved ones; they are afraid that death will cause them pain and suffering and their sense of dignity will be threatened. Meanwhile, the humanistic dimension of medicine may bring back the idea of having conversations with patients - about living and dying alike [15].

Storytelling in palliative care is a way to involve patients and health professionals in the palliative care process and combat the sense of emptiness that comes during difficult times [3]. Narrative medicine is the implementation of the patient-centred care idea; the special role of the humanistic perspective in the advanced disease stages is emphasized as well [3]. Upon learning that they suffer from an incurable disease, patients have many questions and often recall their past to take stock of their lives. At this point, health care professionals should try to guide the patients' thought processes, however, they should also make a key request to every patient - "tell me your story". All patients have their own personal narratives, which are supported by creativity, rich imagination and cognitive engagement.

By having someone listen to their stories, patients do not feel lonely and can transform chaos stories into quest stories. Quest stories make it possible to partially understand the chaos that the patients have suddenly found themselves in [16], as well as to find meaning, organise one's thoughts and attain acceptance - their primary goal [13]. The point of view of each participant of the treatment process is vital, including the patient, family, relatives, doctor and medical staff. Storytelling has been deeply rooted in humans since the dawn of time and listening attentively and empathetically allows the patients to transcend and create a new script - a scenario that gives them a chance to find themselves in a new situation [13].

Doctors value the time spent with patients and building relationships as a form of supportive therapy, regardless of the diagnosis and prognosis. Literature promotes the idea of appreciating the "here and now" and the joy of interpersonal interaction [17]. A good doctor-patient relationship is characterised by the continuity of care and trust based on medical knowledge, combined with empathic communication [2]. Narrative interventions are aimed at improving the mutual understanding, well-being and quality of life of palliative care patients [18]. The stories, insights and experiences of patients and their caretakers may help reduce the risk of implementing improper testing or treatment [19].

Narrative medicine is a key element of patient care, significantly improving both health and quality of life. 
By paying attention to the meaning of the story the patient tells about his or her life, it is possible to make death less frightening and isolating, as death gives meaning to one's life and becomes part of its history. There is nothing more precious than feeling that your existence matters, and it is the doctors' responsibility to make death the final chapter of life and give it a meaningful human experience [3].

\section{Narrative medicine and educating medical personnel}

When it comes to the difficulties in providing palliative care to patients, medical personnel typically point to bureaucratic procedures, inadequate communication - both among professionals themselves and between patients and doctors, as well as factors related to palliative education [20]. In regard to gaining knowledge and experience, it is worth to mention the beginning of the doctors' professional career, as changing one's role from a medical student to a fully-fledged medical professional may cause a plethora of difficulties. Responsibility and decision making affect the shaping of a new personal and professional identity. Newly-educated doctors adapt to their role through the experience of participation, perceived as a series of challenges described either as quest or adventure stories. Therefore, it is all the more valuable for older physicians with longer professional experience to share their stories with younger ones, as this allows the latter to realise that the difficulties they encounter are not unusual and are applicable to virtually any physician at some point in their professional development [21].

Promoting a sense of mission and passion for their profession among doctors is another interesting issue. By sharing their thoughts, the medical staff gain an additional support mechanism and learn that regardless of where they work, doctors and nurses often face similar challenges. On the other hand, this proves that helping ill people and affecting the lives of others makes it possible to find the meaning of one's existence $[22,23]$. Stories told by doctors have an important educational value and enable the development of social and communication competencies. Budlovsky described her experiences while working in a hospital's emergency department, where one of the patients was Audrey - a mother of two who was diagnosed with breast cancer [24]. She quoted fragments of conversations and described searching for answers to the patient's difficult questions, like: "Am I dying?", "When will I die?". While Budlovsky felt helpless, she understood how important it is to listen and allow the patient to speak freely to get to know them better and understand what they fear; to simply let them be human [24].

Residents are aware that the therapy process is not only about a pharmacological treatment or technological background but also listening to patients and their families carefully and empathetically. Nonetheless, this does not change the fact that doctors often prefer to avoid difficult conversations that make them feel helpless [13]. Communicating with patients who need palliative care is difficult for the entire medical team. Its most important aspects include the style, content and sensitivity of the messages conveyed, as such messages concern matters which are vital for patients, i.e. existential issues and the meaning of life. This specific and complex type of communication consists of verbal and non-verbal, as well as intended and unintended messages. Conflicts between patients and medical staff can result in a lack of the patient's consent for treatment or a patient feeling a sense of disrespect. The negative effects of communication errors may include loss of hope, feeling of abandonment and compromised personal dignity and self-esteem [25]. Medical students who learned about patient narratives and perspectives during palliative care classes presented a higher degree of empathy in the future [13].

Conveying unpleasant messages is among the greatest challenges for any doctor $[26,27]$. It is important to carefully listen to the patient and their family to provide them with the best possible support; yet, sometimes silence matters as well. Cerceo described a situation where she told her patient that the cancer was progressing [28]. The patient continued radiotherapy and finished chemotherapy, but still suffered from severe abdominal pains. Eventually, Cerceo saw the result of a CT scan, which showed that the highest number of metastases was located in the abdominal cavity. The patient asked: "how can I say my farewells to my children?" and the doctor replied: "I don't know". Silence ensued. As Cerceo recalls, her music teachers used to say: "it is the silence, not the notes, that creates beauty in a piece of music" [28]. It is the here and now that counts, and while not always comfortable, silence should not be something to be afraid of. Cerceo calls silence a luxury that makes it possible to create the space the patient needs, provide a sense of security and enable them to gather their thoughts; though often underestimated, silence is also a vital element of communication between doctors and patients [28].

Chang described the story of a 20-year-old patient who called off her wedding once she learned that she had cancer so that her husband would not become a widower [29]. Chang also emphasized that "she 
taught me to be silent and stealthy. She taught me to let people, even dying people, just live" [29]. Silence is part of storytelling and thus an integral part of narrative medicine; it has a therapeutic value, allows you to organise your thoughts and distance yourself from the issues at hand, as well as to build doctor-patient relationships, so learning to utilise silence should be part of the medical student education process [30, 31].

The need for innovative, patient-centred communication training is emphasized increasingly often. Wu et al. [32] evaluated the effectiveness of teaching the narrative approach focused on the patient's unique history. The project involved residents and experts from various fields, as well as patients and their families. The training included two 3-hour-long workshops with elements of narrative reflection and educational classes, during which the trainees played the roles of patients and caretakers. Nearly all participants stated that the classes prepared them to communicate with patients on their own, and the percentage of those who said so further increased with every subsequent scenario [32].

Narrative medicine promotes sharing unusual thoughts and solutions. One example is the suggestion to increase the use of poetry reading in palliative care as it helps to create an organised culture, improves team competencies and makes it possible to support patients suffering from serious illnesses. Not only does poetry trigger emotions, but it also promotes new thoughts, whereas group reading makes it possible to find yourself within your community and feel that you are truly part of it. This effectively provides the medical personnel with a fresh perspective - something very valuable in the educational process [33].

\section{Challenges related to narrative medicine}

Although stories told by patients are a true source of knowledge, they also come with their own set of challenges. The most common objection against narrative analyses is related to their subjectivity; it is necessary to take whatever the person sharing his or her story says on faith. It is a kind of a trade-off aimed at ensuring the given person's well-being and providing them with the best care possible while maintaining ethical standards. Language and communication skills are yet another challenge - sometimes a person would like to share more information but such things as their insufficient vocabulary prove to be insurmountable obstacles.

Patient-centred care requires changes to the health care system, including the implementation of programmes aimed at promoting humanistic skills, values and attitudes; this includes financial aspects (and funding for education), as well as the requirement to spend more time with the patients and their relatives, which is not always possible [34]. On the other hand, Cenci points out that any time devoted to narratives also constitutes treatment time, which does not necessarily have to be a burden on the health care system; conversely - it facilitates teamwork and adherence to recommendations and can significantly reduce costs and working time [19].

The cultural context is not at all insignificant either as it plays an important role in the adopted communication models, including conveying unpleasant messages. The SPIKES Protocol (setting, perception, invitation, knowledge, emotions, summary) used in the USA may not always work in non-Anglo-Saxon countries; e.g. in Brazil, it is the family and loved ones who receive all the information first and the whole truth is not always disclosed to the patient [35]. In that case, the prognosis is more of a metaphor or is meant to allow the patient to slowly come to the relevant conclusions. Therefore, knowing the cultural background and the burdens that affect the given person is vital [13].

Active listening significantly contributes to providing effective care, nonetheless, the patient's religion, nationality and cultural background must always be taken into account. In this context, it is worth to refer to one of the patients described by Kheirbek, i.e. Mrs Alam, an 80-year-old Muslim woman who was diagnosed with ovarian cancer [36]. She was an independent person who wished to actively participate in the treatment process. Although 15 years have already passed since her death, Kheirbek still mentions how much he gained thanks to her attitude towards life and death, as well as how valuable a lesson he received at the very start of his medical career. Mrs Alam taught people to be present at any time - here and now - and approach patients with humility and admiration, to open up one's heart and mind and learn about the patients' beliefs. For Mrs Alam, Islam was not only a religion but also a way of life [36].

\section{Summary}

Narrative medicine, i.e. gathering information from patients' stories used in the process of diagnosis and treatment, is an important tool in palliative care. This kind of therapeutic presence is among the medical personnel's most vital skills. The COVID-19 pandemic still causes numerous communication challenges (while writing this article, the epidemic situation in many parts of the world was still dire). The limited physical contact makes the therapeutic presence, as 
well as taking the time to pay attention to the other person especially important.

Dr Danielle Chammas, who worked with many terminal patients, wrote: "we can touch with words, support with silence, speak with our breath and see using sounds" [37]. The current global challenges caused by the pandemic have resulted in teleconsultation via telephone calls and other means of communicators becoming particularly vital, with such services consisting in doctors determining the diagnosis and treatment primarily based on what the patients say [36]. Paradoxically, the restrictions imposed due to the SARS-CoV-2 pandemic - especially regarding direct contact - may help improve the quality of communication, especially in the long term. Today one can look to the future with hope, believing that active listening, mutual understanding and the time devoted to the other person will support the diagnosis and therapy processes in palliative care patients.

\section{Declaration of a conflict of interest}

The authors have no conflicts of interest to declare.

\section{Funding}

This research received no funding.

\section{References}

1. Charon R. What to do with stories: the sciences of narrative medicine. Canadian Family Physician. 2007; 53(8): 1265-1267.

2. Kvåle K, Haugen DF, Synnes O. Patients' illness narratives-From being healthy to living with incurable cancer: Encounters with doctors through the disease trajectory. Cancer Rep (Hoboken). 2020; 3(2): e1227, doi: 10.1002/cnr2.1227, indexed in Pubmed: 32671998.

3. Franke RJ. Focus: The Aging Brain: Palliative Care and the Humanities: Centralizing the Patient at the End of Life. Yale J Biol Med. 2016; 89(1): 105.

4. Hildebrandt $C$, Mayer $H$, Koller A. Experiences of patients with colorectal cancer from diagnosis until completion of treatment: A meta-ethnography approach. Psychooncology. 2019; 28(2): 219-227, doi: 10.1002/pon.4946, indexed in Pubmed: 30447170.

5. Frank AW. The wounded storyteller: Body, illness, and ethics. University of Chicago Press 2013.

6. Rudnik A, Bieńkowski J. Interpretacyjna Analiza Fenomenologiczna w badaniach jakościowych w psychologii... Przegląd najnowszych badań. Annales Universitatis $\mathrm{Pa}$ edagogicae Cracoviensis Studia Psychologica. 2018; 11: 27-38, doi: 10.24917/20845596.11.2.

7. Aoun SM, Nekolaichuk C. Improving the evidence base in palliative care to inform practice and policy: thinking outside the box. J Pain Symptom Manage. 2014; 48(6): 1222-1235, doi: 10.1016/j.jpainsymman.2014.01.007, indexed in Pubmed: 24727305.

8. Charon R. Narrative medicine. New York 2006.

9. Charon R. Narrative medicine: form, function, and ethics. Ann Intern Med. 2001; 134(1): 83-87, doi: 10.7326/0003-4819-134-1-200101020-00024, indexed in Pubmed: 11187429.
10. Beck JR. Conversations With Patients. Clinical J Oncol Nurs. 2018; 22(5): 481-482.

11. Charon R, Wyer P. Narrative evidence based medicine. Lancet. 2008; 371(9609): 296-297.

12. Stanley $P$, Hurst M. Narrative palliative care: a method for building empathy. J Soc Work End Life Palliat Care. 2011; 7(1): 39-55, doi: 10.1080/15524256.2011.548046, indexed in Pubmed: 21391077.

13. De Benedetto MA, de Castro AG, de Carvalho E, et al. From suffering to transcendence: narratives in palliative care. Can Fam Physician. 2007; 53(8): 1277-1279, indexed in Pubmed: 17872834.

14. Walter S, Keinki C, Hübner J. [Treatment decisions in oncology : Walking the tightrope between honesty and hope, lifetime, and quality of life]. HNO. 2020; 68(7): 492-497, doi: 10.1007/s00106-020-00842-z, indexed in Pubmed: 32161976.

15. Holstein M. Reflections on death and dying. Academic medicine: Journal of the Association of American Medical Colleges. 1997; 72(10): 848-855.

16. Cierpka A, Małek K, Horodeńska M. Original article What does it mean to live after heart transplantation? The lived experience of heart transplant recipients. A qualitative study. Health Psychology Report. 2015; 2: 123-130, doi: 10.5114/hpr.2015.49678.

17. Kitayama K. A cup of magic. Patient Educ Couns. 2019; 102(1): 180-181, doi: 10.1016/j.pec.2018.08.035, indexed in Pubmed: 30205920.

18. Laskow T, Small L, Wu DS. Narrative Interventions in the Palliative Care Setting: A Scoping Review. J Pain Symptom Manage. 2019; 58(4): 696-706, doi: 10.1016/j.jpainsymman.2019.06.009, indexed in Pubmed: 31216430.

19. Cenci C. Narrative medicine and the personalisation of treatment for elderly patients. Eur J Intern Med. 2016; 32: 22-25, doi: 10.1016/j.ejim.2016.05.003, indexed in Pubmed: 27210901.

20. Carey ML, Zucca AC, Freund MAg, et al. Systematic review of barriers and enablers to the delivery of palliative care by primary care practitioners. Palliat Med. 2019; 33(9): 1131-1145, doi: 10.1177/0269216319865414, indexed in Pubmed: 31630630.

21. Yardley S, Kinston R, Lefroy J, et al. ,What do we do, doctor?' Transitions of identity and responsibility: a narrative analysis. Adv Health Sci Educ Theory Pract. 2020; 25(4): 825-843, doi: 10.1007/s10459-020-09959-w, indexed in Pubmed: 31960189.

22. Colgan R. I remember...it was December. Ann Fam Med. 2014; 12(3): 276-278, doi: 10.1370/afm.1622, indexed in Pubmed: 24821900.

23. Hebblewhite A. A medical student's reflection on palliative care: Managing emotional connection with patients. Palliat Support Care. 2015; 13(2): 405-408, doi: 10.1017/S1478951513001284, indexed in Pubmed: 24576462.

24. Budlovsky B. Finding the humanity: Learning to listen in emergency medicine. CJEM. 2018; 20(5): 786-787, doi: 10.1017/cem.2018.405, indexed in Pubmed: 30010521.

25. Coyle N, Sculco L. Communication and the patient/physician relationship: a phenomenological inquiry. J Support Oncol. 2003; 1(3): 206-215, indexed in Pubmed: 15334876.

26. Sobczak K, Pawłowski L, Pietrzykowska M, et al. Delivering bad news by physicians - Polish reality check. Journal of Medical Science. 2016; 85(3): 172, doi: 10.20883/jms.2016.117.

27. Sobczak K, Leoniuk K, Janaszczyk A. Delivering bad news: patient's perspective and opinions. Patient Prefer Adhe- 
rence. 2018; 12: 2397-2404, doi: 10.2147/PPA.S183106, indexed in Pubmed: 30519005.

28. Cerceo E. The spaces in between. CMAJ. 2017; 189(24): E838-E839, doi: 10.1503/cmaj.161159, indexed in Pubmed: 28630362.

29. Chang RY. Only life. Can Fam Physician. 2015; 61(1): 66-7, e60, indexed in Pubmed: 25609524.

30. Hoffman MR, Hoffman MR. The Sound of Silence-When There Are No Words. JAMA. 2019; 322(2): 117-118, doi: 10.1001/jama.2019.8385, indexed in Pubmed: 31287526.

31. Lau SY. Dear Mrs. P. CMAJ. 2019; 191(6): E168-E169, doi: 10.1503/cmaj.181235, indexed in Pubmed: 31009378.

32. Wu DS, Kern DE, Dy SM, et al. Narrative Approach to Goals of Care Discussions: A Novel Curriculum.J Pain Symptom Manage. 2019; 58(6): 1033-1039.e1, doi: 10.1016/j.jpainsymman.2019.08.023, indexed in Pubmed: 31472275.

33. Davies EA. Why we need more poetry in palliative care. BMJ Support Palliat Care. 2018; 8(3): 266-270, doi: 10.1136/bmjspcare-2017-001477, indexed in Pubmed: 29574424.
34. Gilligan MC, Osterberg LG, Rider EA, et al. Views of institutional leaders on maintaining humanism in today's practice. Patient Educ Couns. 2019; 102(10): 1911-1916, doi: 10.1016/j.pec.2019.04.025, indexed in Pubmed: 31097330.

35. Sobczak K. Przekazywanie informacji o niekorzystnej diagnozie i rokowaniu. Forum Med Rodz. 2014; 8(6): 320-328.

36. Kheirbek RE. Behind the Veil. Acad Med. 2016; 91(11): 1575, doi: 10.1097/ACM.0000000000001366, indexed in Pubmed: 27779532.

37. Chammas D. Seeing With My Ears. J Pain Symptom Manage. 2020 [Epub ahead of print], doi: 10.1016/j.jpainsymman.2020.09.027, indexed in Pubmed: 32976945.

38. Sutherland AE, Stickland J, Wee B. Can video consultations replace face-to-face interviews? Palliative medicine and the Covid-19 pandemic: rapid review. BMJ Support Palliat Care. 2020; 10(3): 271-275, doi: 10.1136/bmjspcare-2020-002326, indexed in Pubmed: 32457086. 


\section{Znaczenie medycyny narracyjnej w opiece paliatywnej}

Artykuł jest tłumaczeniem pracy: Rudnik A., Sobczak K. The importance of narrative medicine in palliative care. Palliat. Med. Pract. 2021, tom 15, nr 1: 64-69.

Należy cytować wersję pierwotną.

\section{Streszczenie}

W artykule omówiono medycynę narracyjną, czyli czerpanie wiedzy z narracji pacjentów i personelu medycznego. Pozyskane w ten sposób informacje mogą być wykorzystane w procesie ustalania rozpoznania i leczenia, posiadają również wartość edukacyjną. Celem artykułu było przedstawienie znaczenia stosowania takiego rozwiązania $w$ opiece paliatywnej i budowaniu relacji pomiędzy lekarzem a pacjentem. Wskazano na wyzwania związane z narracją i określenie ich szczególnego znaczenia w obecnej sytuacji pandemii COVID-19.

Palliat Med Pract 2021; 15, 1: 70-75

Słowa kluczowe: komunikacja, kontekst kulturowy, medycyna narracyjna, narracje, opowiadanie

Dla ludzi życie ma sens, ponieważ jest opowieścią

(Franke, 2016)

\section{Wstęp}

Medycyna narracyjna podkreśla, w jaki sposób historie opowiadane zarówno przez pacjentów, jak i personel medyczny, mogą zwiększyć empatię i dostarczyć istotnych informacji na temat interpretacji i nadawania znaczenia sytuacji choroby i leczenia [1, 2]. W ostatnich latach zyskała na znaczeniu i popularności, zwłaszcza w opiece paliatywnej [3, 4]. W tym kontekście głównym celem medycyny narracyjnej jest kompleksowa opieka nad pacjentami, rozpoznawanie i interpretowanie narracji dotyczących chorób poprzez integrację nauk społecznych z medycyną. Szczególnie istotne jest wzmocnienie relacji lekarz-pacjent i zapewnienie bardziej humanitarnej, etycznej i skutecznej opieki skoncentrowanej na pacjencie. Podnoszenie kompetencji w tej dziedzinie poprawia nie tylko sam proces komunikacji, ale także pozytywnie wpływa na współpracę w zespole, między innymi dzięki pobudzaniu umiejętności refleksji podnosi poziom profesjonalizmu $[3,5]$.

W badaniach naukowych wzrasta popularność metod jakościowych, w tym analiz narracji badanych [6], co dotyczy również opieki paliatywnej [7]. Tymczasem narracje pacjentów z chorobami przewlekłymi stanowią nie tylko interesujący materiał do analiz naukowych, ale także bazę wspomagającą proces roz-

\section{Adres do korespondencji:}

Agata Rudnik

Instytut Psychologii Uniwersytetu Gdańskiego

e-mail: agata.rudnik@ug.edu.pl 
poznania i leczenia. Aktywne uczestnictwo w procesie dzielenia się przez pacjenta historią choroby istotnie poprawia komunikację pomiędzy chorymi a personelem medycznym, a także podnosi poziom jakości życia zarówno chorych, jak i osób, które się nimi opiekują, w tym pracowników ochrony zdrowia. Wysłuchanie opowieści o chorobie zwiększa zaufanie do personelu, medycyny jako nauki i wpływa pozytywnie na wzrost poczucia godności, ponadto medycyna narracyjna sprzyja przemyśleniom, byciu tu i teraz oraz głębszemu zastanowieniu się nad sensem życia [3].

Za twórczynię medycyny narracyjnej uważa się Ritę Charon z Columbia University, która po raz pierwszy użyła tego określenia w 2000 roku, odnosząc się do praktyki klinicznej wzmocnionej kompetencjami narracyjnymi, a więc umiejętnością interpretowania i zanurzania się w historiach o chorobie [1, 8]. Badania autorki dotyczą głównie komunikacji pomiędzy lekarzem a pacjentem i wykorzystania kompetencji narracyjnych (narrative competence) do poprawy jakości opieki medycznej $[8,9]$. Według Rity Charon choroba i proces zdrowienia to tak zwane akty narracyjne (narrative acts), a pisanie o własnych doświadczeniach przez lekarzy i pacjentów pozwala zwerbalizować i usystematyzować chaos związany z sytuacją choroby [9]. Zdanie Charon podziela Beck, który zaznacza, że „poświęcając czas na rozmowę z moimi pacjentami o ich życiu zauważyłem, że nawiązujemy relację terapeutyczną, które daje korzyści nam obojgu" (by taking the time to talk with my patients about their lives, I find that we establish a rapport over time that is personally rewarding for both of us) [10]. Autor podkreśla również, że pisanie narracji przez lekarzy nadaje praktyce medycznej wyjątkowy rodzaj zrozumienia.

Rita Charon używa również pojęcia medycyny narracyjnej opartej na dowodach (NEBM, narrative evidence based medicine), która z założenia czerpie z wszelkich źródeł, między innymi z tekstów narracji choroby pisanych przez pacjentów (patient-written illness narratives), estetycznych teorii choroby (aesthetic theories of illness) czy fenomenologicznych teorii ucieleśnienia (phenomenological theories of embodiment) [11]. Medycyna narracyjna oparta na dowodach opiera proces rozpoznania i leczenia na ugruntowanej, rygorystycznej, osobistej i konkretnej interpretacji uzyskanych informacji i hipotez [11].

\section{Medycyna narracyjna w opiece paliatywnej}

Wskazuje się, że medycyna narracyjna wspiera zróżnicowane kompetencje pracowników ochrony zdrowia [3, 8], a celem jest wzmocnienie relacji le- karz-pacjent poprzez zapewnienie odpowiedniej, etycznej i skutecznej opieki skoncentrowanej na pacjencie [3]. Integracja medycyny narracyjnej i opieki paliatywnej wydaje się być skutecznym sposobem radzenia sobie w trudnej sytuacji, jaką stanowi poważna choroba i śmierć [12]. Jak pisze DeBenedetto i wsp. „kiedy okazuje się, że nic nie możemy zrobić, nadal możemy słuchać" (when there is apparently nothing to do, one can still listen) $\mathrm{i}$, jeżeli jedynym możliwym zakończeniem opowieści jest śmierć, może zostać napisana na wiele sposobów" (if a story's only possible ending is death, it can be written in many ways) [13].

Relacja pacjent-lekarz odgrywa istotną rolę $w$ procesie leczenia, wpływa między innymi na procesy decyzyjne dotyczące podejmowania i kontynuowania terapii. Jest to istotny czynnik w onkologii i w opiece paliatywnej, nierzadko personel medyczny balansuje pomiędzy szczerością a dawaniem nadziei. Otwarta komunikacja pozwalająca zachować godność i autonomię chorych, chociaż istotna w leczeniu wielu chorób, nabiera tutaj wyjątkowego znaczenia [14]. Pacjenci z nieuleczalną chorobą często czują się odizolowane od otaczającego ich życia i nierzadko mają poczucie, że stanowią ciężar dla najbliższych, obawiają się, iż śmierć będzie przepełniona bólem i cierpieniem, a ich poczucie godności będzie zagrożone. Tymczasem humanistyczny wymiar medycyny może przywrócić prowadzenie z chorymi rozmów, zarówno o życiu, jak i o umieraniu [15].

Narracja w opiece paliatywnej stanowi jeden ze sposobów włączenia pacjentów i pracowników ochrony zdrowia w proces opieki paliatywnej i wypełnienia poczucia pustki, która pojawia się w trudnym czasie [3]. Medycyna narracyjna stanowi realizację idei opieki skoncentrowanej na pacjencie (patient-centred care), podkreślana jest szczególna rola perspektywy humanistycznej w zaawansowanej fazie choroby [3]. Kiedy pacjenci dowiadują się, że cierpią na nieuleczalną chorobę, mają wiele pytań, wracają do przeszłości i dokonują podsumowań swojego życia. Na tym etapie pracownicy ochrony zdrowia powinni starać się kierować myślami chorych, przedtem jednak powinni skierować do pacjenta kluczową prośbę: opowiedz mi swoją historię. Każdy pacjent posiada własną, osobistą narrację, której sprzyja zaangażowanie poznawcze, bogata wyobraźnia i kreatywność.

Dzięki wysłuchaniu pacjenci nie czują się samotni, moga przekształcać historie chaosu (chaos stories) w historie poszukiwań (quest stories). Historie poszukiwań pozwalają w pewnym stopniu zrozumieć panujący chaos, który niejako "spadł" na pacjenta [16], umożliwiają odnalezienie znaczenia, zorganizowanie myśli, a ich głównym celem jest osiągnięcie akceptacji [13]. Istotny jest punkt widzenia każdego 
uczestnika procesu leczenia, w tym chorego, rodziny, bliskich, lekarza i personelu medycznego. Narracja (story telling) jest silnie zakorzeniona w ludziach od zarania dziejów, a słuchanie z uwagą i empatią pozwala pacjentowi na transcendencję i stworzenie nowego skryptu — scenariusza dającego szansę odnalezienia się w nowej sytuacji [13].

Lekarze cenią czas spędzony razem z pacjentem, a także budowanie relacji, będącej formą terapii wspierającej, niezależnie od rozpoznania i rokowania. Literatura zachęca do doceniania i doświadczania „tu i teraz" i czerpania radości z interakcji międzyludzkich [17]. Dobrą relację lekarz-pacjent charakteryzuje ciągłość opieki i zaufanie oparte na wiedzy medycznej, połączone z empatyczną komunikacją [2]. Interwencje narracyjne mają na celu poprawę obopólnego zrozumienia, samopoczucia i jakości życia pacjentów objętych opieką paliatywną [18]. Historie chorych i opiekunów, ich wyobrażenia, spostrzeżenia i doświadczenia mogą zmniejszyć ryzyko przeprowadzenia niewłaściwych badań czy wdrożenia nieprawidłowego leczenia [19].

Medycyna narracyjna stanowi kluczowy element opieki nad pacjentem, wpływając znacząco na poprawę stanu zdrowia i jakości życia. Zwracając uwagę na sens historii, jaką chory tworzy o swoim życiu, śmierć może stać się mniej przerażająca i mniej izolująca, śmierć bowiem nadaje sens naszemu życiu i staje się częścią jego historii. Nic nie może być cenniejsze od poczucia, że nasze istnienie ma znaczenie, a zadaniem lekarzy jest uczynienie ze śmierci ostatniego rozdziału życia i nadanie jej wymiaru znaczącego, ludzkiego doświadczenia [3].

\section{Medycyna narracyjna a edukacja personelu medycznego}

Spośród trudności w zapewnieniu opieki paliatywnej pacjentom, personel medyczny najczęściej, poza procedurami biurokratycznymi, wskazuje na nieodpowiednią komunikację zarówno pomiędzy specjalistami, jak i z chorymi, a także na czynniki związane z edukacją w tym zakresie [20]. W kontekście zdobywania wiedzy i doświadczenia, warto wspomnieć o początku drogi zawodowej lekarzy, kiedy zmiana roli studenta medycyny na rolę lekarza może powodować wiele trudności. Odpowiedzialność i podejmowanie decyzji związane są z kształtowaniem nowej tożsamości osobistej i zawodowej. Nowo wykształceni lekarze adaptują się do swojej roli poprzez doświadczenie udziału postrzegane, jako seria wyzwań, które opowiadane są jako historie przygody lub poszukiwania. Tym cenniejsze jest dzielenie się własnym doświadczeniem przez lekarzy z dłuższym stażem, co pozwala przekonać się o tym, że napotkane trudności nie są niczym niezwykłym i dotyczą w zasadzie każdego lekarza na danym etapie rozwoju zawodowego [21].

Interesującym aspektem jest wspieranie lekarzy w poczuciu pełnienia misji i pasji wykonywania zawodu. Dzielenie się przemyśleniami przez personel medyczny odgrywa rolę wsparcia i wskazuje, że niezależnie od miejsca, lekarze i pielęgniarki często zmagają się z podobnymi wyzwaniami. Z drugiej strony, są dowodem na to, że pomoc chorym i wpływ na życie innych umożliwia odnalezienie sensu własnego istnienia [22, 23]. Historie opowiadane przez lekarzy posiadają istotną wartość edukacyjną i pozwalają rozwijać kompetencje komunikacyjne i społeczne. Budlovsky opisała własne doświadczenia podczas pracy na oddziale medycyny ratunkowej, gdzie jedną z pacjentek była Audrey, matka dwójki dzieci, z rozpoznaniem nowotworu piersi [24]. Autorka przytoczyła fragmenty rozmów i poszukiwanie odpowiedzi na trudne pytania: czy umieram? kiedy umrę? Lekarka czuła się bezradna, ale zrozumiała, jak ważne jest słuchanie i pozwolenie na swobodne wypowiedzi, aby lepiej poznać chorych i zrozumieć, czego się obawiają; po prostu — bycie człowiekiem [24].

Rezydenci zdają sobie sprawę, że proces terapii, to nie tylko leczenie farmakologiczne czy zaplecze technologiczne, ale także uważne i empatyczne słuchanie pacjentów i ich rodzin. Nie zmienia to jednak faktu, że nierzadko lekarze woleliby uniknąć trudnych rozmów, które sprawiają, że czują się bezradni [13]. Komunikacja z pacjentem wymagającym opieki paliatywnej stanowi trudną sytuację dla całego zespołu medycznego. Do najważniejszych aspektów zaliczane są między innymi styl i treść komunikatów oraz wrażliwość przekazu, gdyż dotyczy spraw najbardziej istotnych dla chorych: kwestii egzystencjalnych i sensu życia. Na tę specyficzną i złożoną komunikację składają się zarówno komunikaty werbalne, jak i niewerbalne oraz wiadomości zamierzone i niezamierzone. Konflikt pomiędzy pacjentem a personelem medycznym może obejmować, między innymi brak zgody odnośnie sposobu leczenia czy poczucie braku szacunku. Do negatywnych skutków błędów komunikacyjnych zaliczyć można utratę nadziei, wrażenie opuszczenia, osłabienie poczucia osobistej godności i wartości [25]. Studenci medycyny, którzy podczas zajęć opieki paliatywnej poznawali narracje i perspektywy pacjentów, w przyszłości prezentowali wyższy stopień empatii [13].

Przekazywanie niepomyślnych wiadomości stanowi jedno z największych wyzwań dla lekarzy [26, 27]. Istotne jest, aby w pełni wysłuchać pacjenta i rodzinę, aby udzielić jak najlepszego wsparcia, a niekiedy liczy się cisza. Cerceo opisała sytuację, w której powiedziała 
pacjentowi, że choroba nowotworowa postępuje [28]. Chory kontynuował radioterapię i zakończył chemioterapię, jednak występowały nasilone bóle brzucha. Lekarka obejrzała wynik badania tomografii komputerowej, które wykazało największą liczbę przerzutów w jamie brzusznej. Pacjent zapytał: jak mogę pożegnać się z dziećmi, a lekarka odpowiedziała: nie wiem. Zapadła cisza. Jak wspomina Cerceo, jej nauczyciele muzyki mawiali: Piękno muzyki tworzy cisza, a nie nuty (it is the silence, not the notes, that creates beauty in a piece of music) [28]. Liczy się bowiem tu i teraz, a ciszy nie należy się obawiać, chociaż nie zawsze jest wygodna. Cisza, nazywana przez Cerceo luksusem, pozwala stworzyć przestrzeń, której potrzebuje pacjent, umożliwia zebranie myśli i może zapewnić poczucie bezpieczeństwa; cisza jest również istotnym, chociaż niekiedy niedocenianym, elementem komunikacji pomiędzy lekarzem a pacjentem [28].

Chang opisała historię 20-letniej pacjentki, która po otrzymaniu informacji o rozpoznaniu nowotworu odwołała ślub, aby mąż nie został wdowcem [29]. Autorka podkreśliła, że pacjentka nauczyła ją być cichą i mało widoczną, pozwalać ludziom, nawet umierającym, po prostu żyć (she taught me to be silent and stealthy. She taught me to let people, even dying people, just live) [29]. Cisza stanowi część opowiadania historii i tym samym jest nieodłącznym elementem medycyny narracyjnej, posiada wartość terapeutyczną, pozwala na uporządkowanie myśli, nabranie dystansu, buduje relacje pomiędzy lekarzem a pacjentem, dlatego czerpanie z ciszy powinno stanowić element edukacji studentów medycyny [30, 31].

Coraz częściej podkreślana jest potrzeba innowacyjnych, skoncentrowanych na pacjencie szkoleń w zakresie porozumiewania. Oceny efektywności nauczania podejścia narracyjnego, skoncentrowanego na wyjątkowej historii chorego, dokonali Wu i wsp. [32]. Do projektu zaangażowano ekspertów z różnych dziedzin, lekarzy rezydentów, pacjentów i ich rodziny. Szkolenie obejmowało dwa 3-godzinne warsztaty z elementami refleksji narracyjnej i zajęcia dydaktyczne, podczas których stażyści odgrywali role opiekunów i pacjentów. Niemal wszyscy uczestnicy stwierdzili, że zajęcia przygotowały ich do samodzielnego prowadzenia rozmów, a odsetek ten wzrastał wraz z odgrywaniem kolejnych scenariuszy [32].

Medycyna narracyjna sprzyja dzieleniu się nietypowymi przemyśleniami czy rozwiązaniami. Przykładem może być sugestia, że w opiece paliatywnej częściej powinno być wykorzystywane czytanie poezji, co sprzyja tworzeniu kultury organizacji, podniesieniu kompetencji zespołu i wspieraniu pacjentów z poważnymi chorobami. Poezja nie tylko wyzwala emocje, ale pozwala tworzyć nowe myśli, a wspólne czytanie umożliwia odnalezienie się w społeczności i poczucie bycia jej częścią, dzięki czemu personel medyczny zyskuje nową optykę, świeże spojrzenie, co jest cenne w procesie edukacji [33].

\section{Wyzwania medycyny narracyjnej}

Chociaż historie pacjentów opisane i opowiedziane stanowią prawdziwe źródło wiedzy, związane są jednak z różnego rodzaju trudnościami. Najczęstszym zarzutem wobec analiz narracyjnych jest ich subiektywizm; konieczne jest zaufanie osobie, która dzieli się swoją historią. To pewnego rodzaju sojusz mający na celu dobro drugiego człowieka i zapewnienie możliwie najlepszej opieki, przy zachowaniu norm etycznych. Inne wyzwania stanowią kompetencje językowe i komunikacyjne - nierzadko rozmówca chciałby podzielić się większą liczbą informacji, chciałby przekazać więcej, ale na przeszkodzie staje chociażby niewystarczający zasób słownictwa.

Opieka zorientowana na pacjenta wymaga wprowadzania zmian w systemie ochrony zdrowia, w tym między innymi realizowania programów podnoszących umiejętności, wartości i postawy humanistyczne, co dotyczy również kwestii finansowych (w tym funduszy przeznaczonych na edukację) i wymogów poświęcania pacjentowi i jego bliskim większej ilości czasu, co nie zawsze jest możliwe [34]. Z drugiej strony, jak podkreśla Cenci, czas narracji to również czas leczenia, który niekoniecznie musi stanowić obciążenie dla systemu opieki zdrowotnej, wręcz przeciwnie, ułatwia przestrzeganie zaleceń i pracę zespołową, może znacznie skrócić czas pracy i koszty [19].

Nie bez znaczenia jest także kontekst kulturowy, który odgrywa istotną rolę $\mathrm{w}$ zakresie przyjętych modeli komunikowania się, w tym przekazywania niepomyślnych wiadomości. Wykorzystywany w Stanach Zjednoczonych protokół SPIKES (setting, perception, invitation, knowledge, emotions, summary) nie zawsze sprawdzi się w krajach nieanglosaskich, na przykład w Brazylii, w pierwszej kolejności rodzina i bliscy otrzymują wszystkie informacje, a cała prawda nie zawsze jest przekazywana pacjentowi [35]. Rokowanie jest przekazywane chorym raczej $w$ formie metafor bądź pozwala pacjentom powoli, krok po kroku, dojść do prawdy, istotne jest więc, poznanie zaplecza kulturowego i obciążeń, jakie dotyczą danej osoby [13].

Aktywne słuchanie istotnie przyczynia się do zapewnienia efektywnej opieki, jednak należy brać pod uwagę narodowość, tło kulturowe i wyznanie pacjenta. Kheirbek opisał jedną z pacjentek, 80-letnią muzułmankę Panią Alam z rozpoznaniem nowotworu jajnika [36]. Była osobą niezależną, która chciała aktywnie 
uczestniczyć w procesie leczenia. Chociaż od śmierci chorej minęło 15 lat, autor wspomniał, jak wiele zyskał, dzięki podejściu pacjentki do życia i śmierci, otrzymał cenną lekcję na początku pracy lekarza. Pani Alam nauczyła obecności w każdej chwili, tu i teraz, podchodzenia do pacjentów z pokorą i podziwem, otwierania serca i umysłu, poszukiwania wiedzy dotyczącej przekonań chorych, bo dla pani Alam islam był nie tylko religią, ale także sposobem życia [36].

\section{Podsumowanie}

Medycyna narracyjna, czyli czerpanie informacji z historii pacjentów, wykorzystywanych w procesie rozpoznania i leczenia, stanowi istotne narzędzie w opiece paliatywnej. Ta pewnego rodzaju obecność terapeutyczna (therapeutic presence) stanowi jedną z najważniejszych umiejętności personelu medycznego. Pandemia COVID-19 (podczas pisania artykułu sytuacja epidemiczna $w$ wielu rejonach świata nadal była trudna) powoduje wiele wyzwań dla komunikacji. Ograniczenie kontaktu fizycznego sprawia, że obecność terapeutyczna, poświecenie czasu i uwagi drugiej osobie nabiera szczególnego znaczenia.

Doktor Danielle Chammas, która wielokrotnie towarzyszyła pacjentom $w$ odchodzeniu, napisała: możemy dotykać słowami, wspierać ciszą, mówić oddechem i widzieć poprzez dźwięki [37]. W obecnym globalnym wyzwaniu szczególnego znaczenia nabrały teleporady - konsultacje poprzez połączenia telefoniczne lub inne komunikatory, podczas których lekarze ustalają rozpoznanie i leczenie, głównie opierając się na przekazie pacjentów [36]. Ograniczenia narzucone przez pandemię SARS-CoV-2, głównie dotyczące kontaktu bezpośredniego, mogą paradoksalnie polepszyć, zwłaszcza w dłuższej perspektywie, jakość komunikacji. Z nadzieją można patrzeć w przyszłość, wierząc, że wzajemne zrozumienie, czas poświęcony drugiej osobie i uważne, aktywne słuchanie będą sprzyjać procesom diagnozy i terapii u pacjentów objętych opieką paliatywną.

\section{Deklaracja konfliktu interesów}

Autorzy oświadczają, że nie występuje konflikt interesów.

\section{Finansowanie}

Badanie nie zostało sfinansowane.

\section{Piśmiennictwo}

1. Charon R. What to do with stories: the sciences of narrative medicine. Canadian Family Physician. 2007; 53(8): 1265-1267.
2. Kvåle K, Haugen DF, Synnes O. Patients' illness narratives-From being healthy to living with incurable cancer: Encounters with doctors through the disease trajectory. Cancer Rep (Hoboken). 2020; 3(2): e1227, doi: 10.1002/cnr2.1227, indexed in Pubmed: 32671998.

3. Franke RJ. Focus: The Aging Brain: Palliative Care and the Humanities: Centralizing the Patient at the End of Life. Yale J Biol Med. 2016; 89(1): 105.

4. Hildebrandt $\mathrm{C}$, Mayer $\mathrm{H}$, Koller A. Experiences of patients with colorectal cancer from diagnosis until completion of treatment: A meta-ethnography approach. Psychooncology. 2019; 28(2): 219-227, doi: 10.1002/pon.4946, indexed in Pubmed: 30447170.

5. Frank AW. The wounded storyteller: Body, illness, and ethics. University of Chicago Press 2013.

6. Rudnik A, Bieńkowski J. Interpretacyjna Analiza Fenomenologiczna $w$ badaniach jakościowych $w$ psychologii... Przegląd najnowszych badań. Annales Universitatis Paedagogicae Cracoviensis Studia Psychologica. 2018; 11: 27-38, doi: 10.24917/20845596.11.2.

7. Aoun SM, Nekolaichuk C. Improving the evidence base in palliative care to inform practice and policy: thinking outside the box. J Pain Symptom Manage. 2014; 48(6): 1222-1235, doi: 10.1016/j.jpainsymman.2014.01.007, indexed in Pubmed: 24727305.

8. Charon R. Narrative medicine. New York 2006.

9. Charon R. Narrative medicine: form, function, and ethics. Ann Intern Med. 2001; 134(1): 83-87, doi: 10.7326/0003-4819-134-1-200101020-00024, indexed in Pubmed: 11187429.

10. Beck JR. Conversations With Patients. Clinical J Oncol Nurs. 2018; 22(5): 481-482.

11. Charon $R$, Wyer $P$. Narrative evidence based medicine. Lancet. 2008; 371(9609): 296-297.

12. Stanley $P$, Hurst M. Narrative palliative care: a method for building empathy. J Soc Work End Life Palliat Care. 2011; 7(1): 39-55, doi: 10.1080/15524256.2011.548046, indexed in Pubmed: 21391077.

13. De Benedetto MA, de Castro AG, de Carvalho E, et al. From suffering to transcendence: narratives in palliative care. Can Fam Physician. 2007; 53(8): 1277-1279, indexed in Pubmed: 17872834.

14. Walter S, Keinki C, Hübner J. [Treatment decisions in oncology : Walking the tightrope between honesty and hope, lifetime, and quality of life]. HNO. 2020; 68(7): 492-497, doi: 10.1007/s00106-020-00842-z, indexed in Pubmed: 32161976.

15. Holstein M. Reflections on death and dying. Academic medicine: Journal of the Association of American Medical Colleges. 1997; 72(10): 848-855.

16. Cierpka A, Małek K, Horodeńska M. Original article What does it mean to live after heart transplantation? The lived experience of heart transplant recipients. A qualitative study. Health Psychology Report. 2015; 2: 123-130, doi: 10.5114/hpr.2015.49678.

17. Kitayama K. A cup of magic. Patient Educ Couns. 2019; 102(1): 180-181, doi: 10.1016/j.pec.2018.08.035, indexed in Pubmed: 30205920.

18. Laskow T, Small L, Wu DS. Narrative Interventions in the Palliative Care Setting: A Scoping Review. J Pain Symptom Manage. 2019; 58(4): 696-706, doi: 10.1016/j.jpainsymman.2019.06.009, indexed in Pubmed: 31216430.

19. Cenci C. Narrative medicine and the personalisation of treatment for elderly patients. Eur J Intern Med. 2016; 32: 22-25, doi: 10.1016/j.ejim.2016.05.003, indexed in Pubmed: 27210901. 
20. Carey ML, Zucca AC, Freund MAg, et al. Systematic review of barriers and enablers to the delivery of palliative care by primary care practitioners. Palliat Med. 2019; 33(9): 1131-1145, doi: 10.1177/0269216319865414, indexed in Pubmed: 31630630.

21. Yardley S, Kinston R, Lefroy J, et al. ,What do we do, doctor?' Transitions of identity and responsibility: a narrative analysis. Adv Health Sci Educ Theory Pract. 2020; 25(4): 825-843, doi: 10.1007/s10459-020-09959-w, indexed in Pubmed: 31960189.

22. Colgan R. I remember...it was December. Ann Fam Med. 2014; 12(3): 276-278, doi: 10.1370/afm.1622, indexed in Pubmed: 24821900.

23. Hebblewhite A. A medical student's reflection on palliative care: Managing emotional connection with patients. Palliat Support Care. 2015; 13(2): 405-408, doi: 10.1017/S1478951513001284, indexed in Pubmed: 24576462.

24. Budlovsky B. Finding the humanity: Learning to listen in emergency medicine. CJEM. 2018; 20(5): 786-787, doi: 10.1017/cem.2018.405, indexed in Pubmed: 30010521.

25. Coyle N, Sculco L. Communication and the patient/physician relationship: a phenomenological inquiry. J Support Oncol. 2003; 1(3): 206-215, indexed in Pubmed: 15334876.

26. Sobczak K, Pawłowski L, Pietrzykowska M, et al. Delivering bad news by physicians - Polish reality check. Journal of Medical Science. 2016; 85(3): 172, doi: 10.20883/jms.2016.117.

27. Sobczak K, Leoniuk K, Janaszczyk A. Delivering bad news: patient's perspective and opinions. Patient Prefer Adherence. 2018; 12: 2397-2404, doi: 10.2147/PPA.S183106, indexed in Pubmed: 30519005.

28. Cerceo E. The spaces in between. CMAJ. 2017; 189(24): E838-E839, doi: 10.1503/cmaj.161159, indexed in Pubmed: 28630362.
29. Chang RY. Only life. Can Fam Physician. 2015; 61(1): 66-7, e60, indexed in Pubmed: 25609524.

30. Hoffman MR, Hoffman MR. The Sound of Silence-When There Are No Words. JAMA. 2019; 322(2): 117-118, doi: 10.1001/jama. 2019.8385, indexed in Pubmed: 31287526.

31. Lau SY. Dear Mrs. P. CMAJ. 2019; 191(6): E168-E169, doi: 10.1503/cmaj.181235, indexed in Pubmed: 31009378.

32. Wu DS, Kern DE, Dy SM, et al. Narrative Approach to Goals of Care Discussions: A Novel Curriculum. J Pain Symptom Manage. 2019; 58(6): 1033-1039.e1, doi: 10.1016/j.jpainsymman.2019.08.023, indexed in Pubmed: 31472275.

33. Davies EA. Why we need more poetry in palliative care. BMJ Support Palliat Care. 2018; 8(3): 266-270, doi: 10.1136/bmjspcare-2017-001477, indexed in Pubmed: 29574424.

34. Gilligan MC, Osterberg LG, Rider EA, et al. Views of institutional leaders on maintaining humanism in today's practice. Patient Educ Couns. 2019; 102(10): 1911-1916, doi: 10.1016/j.pec.2019.04.025, indexed in Pubmed: 31097330.

35. Sobczak K. Przekazywanie informacji o niekorzystnej diagnozie i rokowaniu. Forum Med Rodz. 2014; 8(6): 320-328.

36. Kheirbek RE. Behind the Veil. Acad Med. 2016; 91(11): 1575, doi: 10.1097/ACM.0000000000001366, indexed in Pubmed: 27779532.

37. Chammas D. Seeing With My Ears. J Pain Symptom Manage. 2020 [Epub ahead of print], doi: 10.1016/j.jpainsymman.2020.09.027, indexed in Pubmed: 32976945.

38. Sutherland AE, Stickland J, Wee B. Can video consultations replace face-to-face interviews? Palliative medicine and the Covid-19 pandemic: rapid review. BMJ Support Palliat Care. 2020; 10(3): 271-275, doi: 10.1136/bmjspcare-2020-002326, indexed in Pubmed: 32457086. 